\title{
Memorial: \\ Emer. Prof. Alexander Linczényi, CSc. (1932-2019)
}

\author{
Former Vice President of the European Organization for Quality for the \\ East Block
}

DOI: 10.12776/QIP.V23I3.1348

\author{
Renáta Nováková
}

Received: 22 November 2019 Accepted: 22 November 2019 Published: 30 November 2019

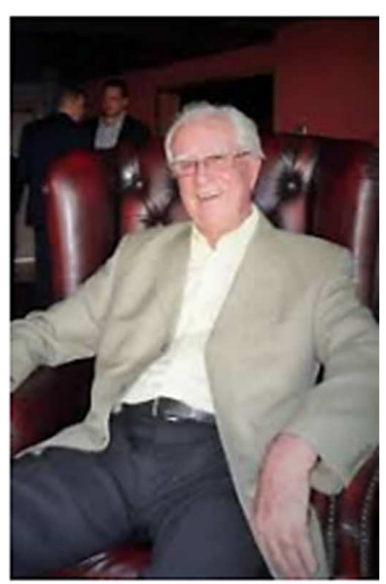

Prof. Linczényi is known as one of the pioneers of quality management in academia and among professionals in former Czechoslovakia. Moreover, he is also considered a father of quality in Slovakia. He held back then the function of Vice President of the European Organization for Quality for the East Block. He was a member of the Association of Scientific and Technical Societies and after the division of the Czech and Slovak Republics, he became actively involved in preparatory activities for the establishment of the Slovak Society for Quality. He worked for more than 40 years as the head of the Quality Management department at STU, based in Bratislava. Professor is an author and co-author of many scientific monographs and textbooks such as, e.g. Engineering Statistics, Quality Management, Distance Learning for Quality Managers, Quality Professional, textbook for Quality Management at Secondary Vocational Schools and many others. He published more than 400 articles in domestic and international magazines and participated at domestic and international conferences, symposia and congresses, e.g. in Australia, China, Israel, Greece, Bulgaria, Hungary, Estonia, Portugal, France, Poland, Czech Republic, Croatia, Montenegro, Germany, Netherlands, etc. Regularly, he also attended congresses organized by the European Organization for Quality. Prof. Linczényi is an author of the economic basis idea for quality management, and in 
his research, he created quality indicators and profitability indicators of quality. One of his contributions can be considered the definition of Creative Quality Management. For his scientific results, he was awarded the title of Scientist of the Year by the president of the Slovak Republic and similarly he was awarded by the Slovak president and Chairman of the Office for Standardization, Metrology and Testing for the lifelong contribution in the area of Quality Management. Slovak Society for Quality had awarded professor for his lifetime work in the area at the occasion of World Quality Day.

\begin{abstract}
ABOUT THE AUTHOR
Renáta Nováková - Associate Professor, director of the Institute of Civil Society, University of Ss. Cyril and Methodius in Trnava, Slovakia. E-mail: renata.novakova@ucm.sk, Author's ORCID: 0000-0003-3106-2709.
\end{abstract}

Conflicts of Interest: The author declares no conflict of interest.

(C) 2019 by the authors. Submitted for possible open access publication under the terms and conditions of the Creative Commons Attribution (CC-BY) license (http://creativecommons.org/licenses/by/4.0/). 